\title{
The Language of Deviant Teaching in Malaysia
}

\author{
Munif Zarirruddin Fikri Nordin
}

School of Languages, Civilization and Philosophy, Universiti Utara Malaysia, 06010 Kedah, Malaysia

\begin{abstract}
As religion covers some abstract and metaphysical concepts, its meanings are subjected to the differences, and somehow interpreted defiantly. This article discusses the language of deviant teaching by referring to the Malay language as a religious language in Malaysia, having the objectives of (1) identifying the pragmatics in the language of deviant teaching, and (2) describing the interpretation of truth in the language of deviant teaching. The discussion is based on the pragmatic concept suggested by Crystal [1]) that language users have choices when using language, and Russell's approach [2] to meaning and interpretation in the philosophy of language. The data used in the discussion relate to the use of Malay Islamic words by two Muslim groups in Malaysia which are identified as deviant teachings, namely Tareqat Amirul Mukminin in the state of Perak and Tarikat al-Tijani in the state of Kelantan. The results show that there is a central cause of pragmatics in the language of deviant teaching which is the formulation of the identity. The results also show that the interpretation of truth in the language of deviant teaching is relatively associated with the cult of the leaders by referring them as being beyond superior and very outstanding.
\end{abstract}

Keywords: Deviant Teaching, Language and Religion, Semantics, Interpretation

Subject Classification: Religious Discourse Analysis

Type (Method/Approach): Textual Analysis

Date of Publication: 2018-08-30

DOI: https://doi.org/10.24297/jal.v9i1.7572

ISSN: 2348-3024

Volume: 09 Issue: 01

Journal: Journal of Advances in Linguistics

Publisher: CIRWORLD

Website: https://cirworld.com

This work is licensed under a Creative Commons Attribution 4.0 International License. 


\section{Introduction}

Dealing with religious meaning is different from other meanings. To understand religious meanings, interpretation takes place so that understanding and practice are parallel with the meanings. As religion covers some sacred and metaphysical concepts, its meanings are subjected to the differences, and somehow interpreted defiantly.

This study examines the language of deviant teaching by referring to the Malay language as a religious language in Malaysia, having the objectives of (1) identifying the pragmatics in the language of deviant teaching, and (2) describing the interpretation of truth in the language of deviant teaching. The discussion is based on the pragmatic concept suggested by Crystal [1] that language users have choices when using language, and Russell's approach [2] to meaning and interpretation in the philosophy of language.

The data used in the discussion relate to the use of Malay Islamic words by two Muslim groups in Malaysia which are identified as deviant teachings by fatwa committees of two states on the controversial issues related to Muslims' belief and practice. The groups are based on tareqat (mystical teaching and spiritual practices with the aim of seeking the ultimate truth), namely Tareqat Amirul Mukminin in the state of Perak and Tarikat alTijani in the state of Kelantan.

\section{Deviance in Religious Language in Malaysia}

In the study of religion, deviant teaching is referred to as uncommon religious practice. It departs from usual or accepted standards of system of belief, ritual and religious behaviour. Hence, deviant teaching is associated with wrong religious understanding and practice. It is a threat to the survival of religion. Every single religion from monotheistic religions with holy texts and messengers to polytheistic religions without any solid sources has its own deviant practice. For instance, although Islam is a perfected and bestowed religion as confirmed by Allah (Quran 5: 3), it is also exposed to uncommon religious understanding and practice [3].

There are two basic elements of religious language in Malaysia. Firstly, it is commonly referred to as the language of Islam as Islam is the federal religion. Islam monopolises publicly the religious discourse in Malaysia. The only religion that has privileges in terms of the propagation, ritual and practice through media is Islam. Other religions' activities are prohibited from being broadcast. The government prescribes that the Sunni sect offers the true way of understanding and practising Islam. Any other Islamic schools of thought are considered deviant [4].

Secondly, the Malay language as a religious language is exclusively the language of Islam. In the Malaysian Constitution, the word 'Malay' and 'Islam' are closely related. All Malays are legally considered Muslims, but not all Muslims are Malays.

\section{The Pragmatics in the Language of Deviant Teaching}

How is language used in deviant teaching? As language is a tool of communication, it is used with a specific intention and purpose underlined by the leader of deviant teaching. There are two groups of deviant teaching, namely Tareqat Amirul Mukminin in the state of Perak and Tarikat al-Tijani in the state of Kelantan which are based on the orientation of tareqat (mystical teaching and spiritual practices with the aim of seeking the ultimate truth).

Tareqat Amirul Mukminin in the state of Perak focuses on belief (aqidah), therefore, it emphasizes on Allah, the Prophet and other pillars of belief. It seems that it takes into consideration a set of basic principles of Islamic belief as practised by Muslims all over the world regardless of their sects and school of thoughts. 
The State of Perak's Fatwa Committee Meeting held on 17-19 September 2014 decided that the tareqat had deviated from the actual teachings of Islam. There were a number of doubtful practices in the tareqat including the statement that most of the Muslims did not have complete faith in Allah and the Prophet as in example (1).

(1) Sesungguhnya kaum-kaum Islam kebanyakan pada masa ini ia belum beriman dengan Allah Taala lagi dan kepada Rasulullah [5]

Translation: Indeed, most of the Muslim tribes presently do not have complete faith in Allah Taala and the Prophet (The State of Perak Darul Ridzuan Mufti Department, 2014)

The tareqat emphasizes on the construction of identity in order to be different from others. Their identification is indicated through the expression "most of the Muslim tribes presently do not have complete faith". They are confident that the people outside their group do not believe in Allah and the Prophet as they do. Hence, they are better than others in terms of the concept and practice of belief. At the same time, the identification makes the followers loyal to their leader.

Semantically, the exclusiveness of identity has created an isolated world-view in the followers' thoughts. Their world-views have been formulated by their leader's language. They measured their faith based on the context that had been constructed. For them, their faith was supreme and they were confident in their faith.

Tarikat al-Tijani in the state of Kelantan is based on pantheism. Historically, the tarikat was brought to Malaysia in 2007, by a Tunisian, namely Ahmad al-Hadi al-Hasani al-Maghribi. He was educated in science and started learning pantheism from a number of teachers of Tarikat al-Tijani in Morocco. He revealed that he was of the 34th generation of the Prophet's family tree, and claimed that he was asked by the Prophet to propagate the tarikat in Malaysia. The centers of the tarikat were based in Kedah, Kelantan, Terengganu dan Selangor [6].

Based on a book entitled Irsyad al-Asfiya'ila Tariqati Khatmul Awlia' (Guidance of Healers towards the Prophet's Pathway), referred by Yahya bin Zakaria and his followers in Kampung Banggol Stol Pasir Mas, Kelantan, the State of Kelantan (2014) declares that the group was deviant. The book indoctrinates that the leader and followers' rewards are always multiplied. It is based on the following evidence in example (2):

(2) Ia seumpama bandingan gandaan pahala yang diperolehi oleh umat Nabi Muhammad SAW berbanding umat yang terdahulu [7]

Translation: It is like a multiple reward obtained by the people of the Prophet Muhammad PBUH, compared to the previous generations (The State of Kelantan Gazzete, 2014)

A multiple reward as understood by the tarikat is the reward gained by the people of the Prophet Muhammad which is far better compared to that of the previous generations.

Semantically, the multiple reward becomes an attractive meaning to the followers of the teaching as it is a spiritual privilege for them. They create their own 'world' by making an assumption that they are granted this privilege although they are following the same practices as the others. This reward package has an additional reward which is a belief that the reward of the people of the Prophet will be doubled. Unlike the previous generations prior to the people of the Prophet, they will be given a privilege in the form of manifold rewards.

\section{The Interpretation of Truth in the Language of Deviant Teaching}

This section may be divided into subsections or may be combined. How is the interpretation of truth made in deviant teaching? The leader of the deviant teaching plays an important role in interpreting the truth through his intention and understanding. As the two groups of Tareqat Amirul Mukminin in the state of Perak and Tarikat al-Tijani in the state of Kelantan are tareqat groups, the leaders are associated with the truth. What 
they clarify as a truth is totally accepted by the followers without question or objection. The leaders' truth is also their truth.

In Tareqat Amirul Mukminin in the state of Perak, the leader describes his followers as better than the people who do not have complete faith as shown in example (3).

(3) Sesungguhnya kaum-kaum Islam kebanyakan pada masa ini ia belum beriman dengan Allah Taala lagi dan kepada Rasulullah [5])

Translation: Indeed, most of the Muslim tribes presently do not have complete faith in Allah Taala and the Prophet (The State of Perak Darul Ridzuan Mufti Department, 2014)

The interpretation is made by taking into consideration their socialization. Since they differentiate themselves from others, they believe that other people are religiously inferior to them. They socially create a gap and keep a distance from others. For them, there is no need to socialize with others, and they are able to fulfil their needs within their own society.

In terms of the impact of the interpretation, as they are mentally and intellectually controlled, they are closeminded and are totally indoctrinated by their leader who claims that his religious knowledge is superior to the mufti's knowledge. The leader's charisma makes them accept the beliefs without any criticism.

As explained by a respondent from the Perak Islamic Religious Department, in order to strengten the truth among the followers, the leader indoctrinates them offensively by threatening scarce rewards and black magic. Apart from that, the leader also discredits the religious authority, assuming that he is holier than others. He tends to misinterprete some keywords, like syafa'at (the privilege given to the Prophet to save his people in the hereafter), wirid, keramat and kasyaf (exploring the secrets of metaphysics through intuition).

Tarikat al-Tijani in the state of Kelantan promotes the belief that its' followers are rewarded abundantly, as shown in example (4).

(4) Mengikut Tarikat al-Tijani, Rasulullah SAW telah memberikan jaminan terhadap para pengikut al-Tijani bahawa setiap pahala kebaikan mereka digandakan [7]

Translation: According to Tarikat al-Tijani, the Prophet has guaranteed that the rewards of tarikat's followers will be multiplied (The State of Kelantan Gazzete, 2014)

In making an interpretation, the followers of the tarikat relate the truth to their practice. For them, the rewards are surely multiplied and it is true because they prove it through their recitation in the tarikat. As long as they practise the tarikat, they are in the right path.

In terms of the impact of the interpretation, the main factor that regulates the belief of the followers is the orientation of the tarikat in upholding their loyalty. The tarikat's leader, namely, Sheikh Ahmad al-Tijani is a very authentic source at all things religious and worldly because he is believed to have a special connection to the Prophet. The blind followers' loyalty makes them stay connected with the tarikat. At the same time, they are threatened with poor rewards if they leave the tarikat.

\section{Conclusions}

The results show that there is a central cause of pragmatics in the language of deviant teaching which is the formulation of the leaders' identity. The results also show that the interpretation of truth in the language of deviant teaching is relatively associated with the cult status of the leaders by referring them as extraordinary and very outstanding. The study contributes to understand how language is used in deviant teaching and why its leaders influence their followers by using language. 


\section{Funding Statement}

This study was funded by Malaysian government through Fundamental Research Grant Scheme (Ref: FRGS/1/2014/SSI01/UUM/02/1).

\section{References}

[1] D. Crystal, Pragmatics, in A. Bullock and S. Trombley (Eds.), The new Fontana dictionary of modern thought, 3 (London: HaperCollinsPublishers 1999) 678.

[2] B. Russell, An inquiry into meaning and truth (London: George Allen and Unwin Ltd, 1940).

[3] Munif Z. F. Nordin, Forensic linguistics and the detecting of deviant teaching in Malaysia, The Euporean Proceeding of Social \& Behavioural Sciences. ISSC 2016: International Soft Science Conference, Langkawi, Kedah, 2016, 275-280.

[4] Munif Z. F. Nordin, Truth and deviation in religious language in Malaysia, Australian Journal of Basic and Applied Sciences, 10(10), 2016, 164-169.

[5] Jabatan Mufti Negeri Perak Darul Ridzuan, The $202^{\text {nd }}$ fatwa committee meeting of of the state of Perak, 2014.

[6] Jabatan Kemajuan Islam Malaysia, Paper presented to the panel of faith research's meeting, Department of Islamic Development Malaysia, for the endorsement of Tarikat at-Tijani in Malaysia, 2012.

[7] Warta Kerajaan Negeri Kelantan, the fatwa of a book entitiled Irsyad Al Asfiya' Ila Tariqati Khatmul Aulia Compiled by Ahmad Al-Hadi Al Hasani Al-Maghribi, translated into the Malay Language (Meniti Jalan Hidayah Menuju Tariqah Khatmul Aulia), practised by Yahya bin Zakaria and his followers in Kampung Banggol Stol Pasir Mas, 2014. 